\title{
Oldest Leaf-Mine Trace Fossil from East Asia and Stoichiometric Footprint: Insight Into Ancient Nutritional Flow in a Plant-Herbivore Interaction
}

Yume Imada ( $\square$ imayume.ac@gmail.com )

Ehime University

Nozomu Oyama

Kyushu University

Kenji Shinoda

Mine City Office

Fumio Takahashi

Mine City Museum of History and Folklore

Hirokazu Yukawa

Fukui Prefectural Dinosaur Museum

\section{Research Article}

Keywords: Plant-insect interactions, palaeobotany, Japan, leaf-mining, Late Triassic, coprolite, elemental analyses, EDS

Posted Date: October 27th, 2021

DOI: https://doi.org/10.21203/rs.3.rs-993678/v1

License: (c) (1) This work is licensed under a Creative Commons Attribution 4.0 International License. Read Full License 


\section{Abstract}

The Late Triassic saw a flourish of plant-arthropod interactions. By the Late Triassic, insects had developed all distinct strategies of herbivory, notably including some of the earliest occurrences of leafmining. Herein we describe exceptionally well-preserved leaf-mine trace fossils on a Cladophlebis fern pinnule from the Momonoki Formation, Mine Group, Japan (Middle Carnian), representing the oldest unequivocal leaf-mines from East Asia. The mines all display a distinctive frass trail - a continuous meandering line, which later becomes a broad blotch containing spheroidal particles - demonstrating larval development. The shapes of these mines generally resemble those of nepticuloid moths, although they are absent from extant fern-mining assemblages. Furthermore, elemental analyses by X-ray fluorescence (XRF) reveals that the frass trail comprises phosphate coprolites. The quantitative variations in $\mathrm{P}, \mathrm{S}$, and $\mathrm{Si}$ between coprolites and leaf veins may reflect physiological processes (consumption, absorption, and excretion) mediated by plant chemicals. Our findings reinforce the idea that leaf-mining had become a pervasive feeding strategy of herbivorous insects by the Late Triassic.

\section{Introduction}

Leaf mining is a means of herbivory by which insects consume live foliage while dwelling inside the hostplant tissue ${ }^{1}$. The biology of leaf-mining has historically attracted much attention and is extensively studied by ecologists ${ }^{2}$. Leaf miners can be identified between species and subfamily level based on mine shape and host-plant taxonomy. Thus plant-insect associations can be reconstructed by analysing mined leaves. Mined leaves also provide information on much of the overall life history of an individual miner: namely, the developmental process, from oviposition, through larval growth and the pupal stage, to adult emergence, is externally traceable, which makes it an ideal system for the study of demography and population dynamics while modelling the rates and causes of mortality (e.g., parasitism, competition) in natural populations ${ }^{3,4}$. As leaf-mining insects afford a wealth of ecological information, they have frequently been used for studying population, community, and evolutionary ecology of plant-insect interactions ${ }^{5-7}$.

The evolution of leaf-mining is a compelling aspect of the development of dietary niches of insects. Insect groups with mining habits have evolved multiple times in several holometabolous insect orders (e.g., Lepidoptera, Coleoptera, Diptera, Hymenoptera) ${ }^{1,8}$. Miners are more susceptible to the chemical defences of host plants and are more severely attacked by parasitoids than external feeders. Thus, they tend to show high host specificity, with many species being monophagous or oligophagous herbivores ${ }^{2,9}$, and they are embedded in a complex multitrophic network ${ }^{10-12}$. Some leaf-mining insect groups have been used for assessing patterns and processes of macroevolution within a phylogenetic framework ${ }^{13-}$ 16 .

Leaf-mining has also been examined in palaeobiological studies because mine trails can be found from impression/compression fossils of plant leaves. In some cases, the leaf miner responsible for the mine is 
assignable to a specific insect group by comparing the shape of the fossil mine and the host-plant taxonomy with analogous extant ones ${ }^{17-21}$; these records can help to time-calibrate insect phylogeny. Furthermore, the specialized damage observed in fossil leaf mines enables us to answer various questions related to dynamic shifts or persistence of plant-insect interactions before and after ecological perturbations ${ }^{22-25}$.

Concerning the evolutionary origin of leaf-mining, however, available information is scarce. The earliest credible occurrence of leaf-mining so far dates back to the Middle-Late Triassic, which is much later than other functional feeding groups: namely, sporangivory, boring, external foliage feeding, seed predation, piercing-and-sucking, and galling ${ }^{26,27}$. Substantial evidence of leaf-mining is, however, very scarce in records preceding the Late Triassic.

Herein we describe a novel type of leaf-mine fossil from the Carnian Momonoki Formation, southwestern Japan. Described below are the exquisitely preserved mines in a Cladophlebis fern frond, and the traces preserve their organic remains. The specimen has already been displayed for years in a cabinet at the Mine City Museum of History and Folklore, Yamaguchi, Japan. The fossil locality is dated to be the Middle Carnian (ca. $220 \mathrm{Ma}$ ), and thus, the mine represents one of the oldest credible leaf-mine fossils worldwide. Additionally, elemental analyses using an X-ray fluorescence (XRF) spectrometer are conducted on the fossil mine, casting new light on this ancient plant-herbivore association from the perspective of ecological stoichiometry.

\section{Materials And Methods}

\section{Geological setting}

The Mine Group, which faces continental China, is located on the northern side of the Median Tectonic Line, which divides the southwest end of Honshu island, Japan (Fig. 1). The stratigraphic setting is subdivided into three strata: the Hirabara, Momonoki, and Aso Formations, in ascending order ${ }^{28,29}$. Study material was obtained from the Momonoki Formation, which yields the most abundant fossil plants and insects $^{30,31}$. The Momonoki Formation is dated to the Middle Carnian (ca. $220 \mathrm{Ma}$ ) based on $\mathrm{U}-\mathrm{Pb}$ age data of detrital zircon ${ }^{32}$, which is consistent with the biostratigraphy of marine and terrestrial invertebrates ${ }^{28,33}$. The Momonoki Formation exceeds $1000 \mathrm{~m}$ in thickness and is conformable with the subjacent Hirabara Formation ${ }^{31,32}$. The sandstones and muddy sandstones of the Momonoki Formation host impressions of plant and insect macrofossils. The holotype specimen was collected by Fumio Takahashi at a road cutting on National Route 435 while the road was under construction; the locality also bore many insect fossils ${ }^{31,34-36}$. The Momonoki Formation is overlain by lacustrine, deltaic, and lagoonal depositional environments ${ }^{37}$, and therefore lacks marine invertebrate fossils, unlike in the Hirabara and Aso Formations ${ }^{30}$. 


\section{Palaeobiological setting}

Plant remains from this locality are primarily represented by impressions of foliage, stem fragments with leaves, and, occasionally, fructifications. The plant assemblage of the Momonoki Formation is composed of ferns, sphenophytes, cycadophytes, ginkgophytes, and conifers ${ }^{38}$. There are three characteristics of the Momonoki Formation that are distinct from some other coeval fossil plant assemblages ${ }^{39}$ : Sphenopsida (e.g., Neocalamites and Equisetites), ferns (e.g., Camptopteris, Clathropteris, Dictyophyllum, Cladophlebis), and conifers (e.g., Podozamites, Cycadocarpidium) are well represented; cycadophytes and ginkgophytes ${ }^{40}$ are common; Danaeopsis and Symopteris (Marattiaceae) ferns are lacking. Liverworts (Pallaviciniites) are also present ${ }^{41}$. The floral composition of the Momonoki Formation is part of the Southern Floristic Region of East Asia ${ }^{39,42}$; the floristic region extends over a broad geographic range, from as far south as Indonesia and north to a small area of northeasten China, and is characterized by the occurrence of Dictyophyllum and Clathropteris ${ }^{39}$.

A diverse fossil insect fauna has been found at the Momonoki Formation ${ }^{36,43}$. These fossils are borne from specific stratigraphic layers of dark, fine-grained siltstones that are devoid of coarse detritus ${ }^{30}$. Most of the insect fossils are isolated wings, but nearly complete bodies are also found ${ }^{36}$. The recorded insects encompass at least 12 orders: Odonata, Ephemeroptera, Blattodea, Plecoptera, Paraplecoptera, Reculida, Neuroptera, Hymenoptera, Coleoptera, Hemiptera, Mecoptera, Diptera ${ }^{31}$. In particular, there are rich yields of wings of Coleoptera (Taldycupedidae) and Blattodea (Mancusoblattidae, Mesoblattinidae) amongst the insect fauna of this deposit ${ }^{31,34}$. Notably, the Momonoki Formation yields true flies ${ }^{36}$, albeit undescribed, which have only been recorded from a few deposits from the Middle-Late Triassic ${ }^{44-49}$. Although more than 6000 specimens of fossil insects are recorded from this formation ${ }^{29,36}$, the taxonomic diversity is largely unexplored, and numerous terrestrial and aquatic insect specimens remain undescribed. At present, 18 species in ten families belonging to seven orders are described ${ }^{31,33-35,43}$. The insect fauna of the Mine Group is thought to have an affinity with four remote localities ${ }^{31,33}$ : the Mount Crosby Formation in Australia, the Madygen Formation in Kyrgyzstan, the Djam Djun Formation in Vietnam, and the Yan-Chen Formation in China.

\section{Methods}

Plant-arthropod interactions were censused for ca. 200 full storage boxes (ca. $536 \times 336 \mathrm{~cm}$ ) of specimens. Thus, the examined surface area of fossils came to no less than $3600 \mathrm{~m}^{2}$; the specimens were collected from several localities of the Momonoki Formation. Although many plant-insect interactions were found, the leaf mines described in this paper were found in only one specimen. Cladophlebis fern fronds were a dominant component of the floral assemblage. Three leaf mines on a shale, as one part and counterpart specimen. The shale was collected from National Route 435 by Fumio Takahashi (Fig. 1). The material is housed in the Mine City Museum of History and Folklore (MMHF), Yamaguchi prefecture, Japan; the catalogue numbers are MMHF11-00001a and MMHF11- 
00001b. The geological map (Fig. 1) was made by H.Y. based on relevant studies ${ }^{90,91}$, and later slightly modified by Y.I., using Adobe Illustrator ${ }^{\circledR} 2021$.

Photographs of materials were taken by N.O. with a Nikon D850 using three types of Macro-NIKKOR lens $(120 \mathrm{~mm} \mathrm{~F} \mathrm{46.3,} 55 \mathrm{~mm} \mathrm{f} 2.8$, and $65 \mathrm{~mm}$ f 4.5). Photos were later edited by Y.I. with Adobe Photoshop® 2021 to increase the contrast and to erase the background. Areas and lengths were measured by Y.I. with Fiji (Fiji Is Just Image J) ${ }^{92}$. For preparing Fig. 4A-F, illustrations were made by Y.I. by tracing photos from the relevant literature with water-based drawing pens, scanned with a CanoScan LiDE 400 (Canon) at a resolution of $300 \mathrm{dpi}$, and edited with Adobe Photoshop® 2021.

To examine the stoichiometric footprint of this ancient plant-insect interaction, elements of the mine trace were analysed by H.Y. via energy-dispersive X-ray fluorescence (XRF) using a EA6000VX High Sensitivity XRF Analyzer (Hitachi High-Tech Science Corporation). An XRF spectrometer measures elements between $\mathrm{Na}$ and $\mathrm{U}$ in order of increasing atomic number. Elemental compositions were quantitatively measured from three points of the holotype specimen where organic compounds derived from fossil leaves remained (one point was set on a frass trail of a leaf mine where insect's coprolites were visible; each one sample point was set on leaf vein and lamina of the same pinnule), and, as a control point, from the specimen's rock matrix. The measurement duration was set at $120 \mathrm{~s}$ using a $0.2 \times$ $0.2 \mathrm{~mm}$ collimator under an excitation voltage of $50 \mathrm{kV}$ and a tube current of $1000 \mu \mathrm{A}$. Output data were visualized by Y.I. with ggplot $2^{93}$ and formatted with Adobe Illustrator ${ }^{\circledR} 2021$.

\section{Results}

Description of trace fossil. Three leaf mines with similar structures are found from five consecutive pinnules of the basiscopic pinna (white arrowheads in Fig. 2A-B). The plant tissues, including the epidermis and veins, stand out sharply against the profoundly weathered matrix of the slab. The laminae of the pinnules with the mines are darker than the uninfected ones, presumably due to the response to herbivory (e.g., necrotic tissue). The mines broadly cover the lamina, although the margins of mined and remaining areas are not clearly distinguished as breached epidermal tissue, indicating that the miners left some tissue layers unconsumed. The mines originate either from the proximal or distal end of the lobes. Starting points (i.e., oviposition site) are obscure or unseen (orange arrowheads in Fig. 2C, D), lying on a secondary leaf vein. Frass trails appear as a narrow sinusoidal threads with a width of $0.5-1.3 \mathrm{~mm}(1.1$ $\mathrm{mm}$ on average), accompanying many close-set hairpin curves with occasional loops. The frass trails subsequently expand into broad bands of width $0.5-0.8 \mathrm{~mm}$, with the dense accumulation of finely divided grains. The frass trails are single, continuous lines but accompanied with a few gaps; altogether, each frass trail covers nearly the entire distal part of a pinnula. Although the trajectories of the frass trails freely extend across the secondary veins, they do not traverse the first veins (i.e., midribs) except those near the leaf apex; such behavioural characteristics thus give the entire mining structure on a pinnule a Ushape. These mines connect to the neighbouring pinnule through the widened base of the pinnule (Fig. $2 D-E)$. The fact that the leaf veins within the mined area are not distorted dictates that the vascular 
bundles are left unconsumed. The necrotic tissue at the end of the mine indicates a possible pupal chamber (pc, Fig. 2D).

Locality. Okubata, Omine, Mine, Yamaguchi.

Age. Carnian.

Stratigraphy. Momonoki Formation, Mine Group, Yamaguchi prefecture, Japan.

Material. A single part-and-counterpart specimen (MMHF11-00001a, MMHF11-00001b; Fig. 2A, 2B, respectively) collected by F.T. from National Route 435 while the road was under construction (Fig. 1).

Host plant. The host plant is considered to be Cladophlebis nebbensis based on the following characteristics. Rachis $3 \mathrm{~mm}$ wide, grooved adaxially and rounded abaxially. Pinna subopposite, attached by a broad base to the rachis at an angle of 70-75 degrees, with internodes of $34 \mathrm{~mm}$; apex unknown. Leaves sterile and bipinnate. Pinnules sessile, subopposite, arising at an angle of 71-81 degrees to the pinna rachis, catadromous in order; acroscopic pinnules slightly longer and narrower than basiscopic ones; close-set, occasionally overlapping. Pinnule about 11-14 mm long and 7-8 mm wide (surface area ca. $91.9 \mathrm{~mm}^{2}$ ), with widened base and obtuse apices; veins catadromous, having distinct primary vein reaching apical margin and 11-13 secondary veins forking once. This species may alternatively be Todites fukutomi ${ }^{50}$, but this possibility is not considered here because some distinguishing characters (e.g., fertile pinnules and twice-forked secondary veins) are lacking in our specimen.

Remarks. The focal Cladophlebis frond is targeted by external foliage feeders in addition to miners. Excisions bordered by evident reaction rims (the area defined by two yellow asterisks in Fig. 2A) indicate signs of external feeding by a mandibulate folivore.

\section{X-ray fluorescence (XRF) analyses}

Elements were quantified at four sample points: (A) frass trail, (B) leaf vein, (C) leaf lamina, (D) rock matrix (Fig. 3). The XRF spectrum detected peaks of ten elements (Al, Si, P, S, K, Ca, Ti, Fe, Sr, Zr); the other peaks were of $\mathrm{Rh}$ gas used for the analyses. The values for four elements $(\mathrm{Si}, \mathrm{P}, \mathrm{S}, \mathrm{Ca}$ ) were particularly notable because these elements could be at least partly biogenic and involved in physiological processes. The leaf lamina was composed of just a thin film of plant tissue, and thus the elemental composition might include that of rock beneath the lamina. The results for the leaf lamina generally showed a similar trend with that of rock; however, $\mathrm{P}$ and $\mathrm{S}$, presumably of biogenic origin, were detected, confirming that leaf tissue was preserved on the rock. We report the results below as the total amount of X-ray per sec (cps). Marked variations were found in Si; it was highest in the leaf lamina (376.457 $\pm 5.394 \mathrm{cps}$ ), slightly higher than in rock (366.144 $\pm 5.323 \mathrm{cps})$, and lowest in the leaf vein $(114.689 \pm 3.029 \mathrm{cps})$. The highest $P$ was recorded in the leaf vein $(11.680 \pm 1.149 \mathrm{cps})$, which was followed by $P$ in frass $(7.923 \pm 0.992$ cps), whereas peaks for $P$ were not detected in the lamina or rock. $S$ showed a similar trend as $P$, but with 
peaks in frass $(29.034 \pm 1.614 \mathrm{cps})$ and the vein $(11.680 \pm 1.149 \mathrm{cps})$ being higher than those of P. Peaks of Ca showed only minor differences among sample points.

\section{Discussion}

\section{Significant features of the mines and the possible culprit}

The Cladophlebis mining structures from the Momonoki Formation are leaf mines by holometabolous insects and can be distinguished from other feeding methods (e.g., surface-feeding) and also from features of taphonomic origin because they more or less satisfy the following criteria for shapes of insect leaf-mines ${ }^{51}$ : an oviposition site at one end of the mining structure; an enlarged oviposition area as a blotch or curvilinear trace; a sign of the evacuated leaf tissue; width of evacuated plant tissue and frass trail increases from one end to the other; the presence of a frass trail, either particulate or fluidized; response tissue along with the marginal tissue; a distinctive terminus, such as an expanded region (chamber). The three mines on the same pinna (Fig. 2A-B) are probably produced by the same insect taxon as they share features of the frass trails. Each mine is composed of a continuous, single frass trail of which the size of pellets subsequently expands at the end. The abrupt change in the faecal shapes can be interpreted as larval development while mining.

Mine morphology and host-plant range often provide us with keys to identify leaf-mining insects because leaf-mining insects tend to be associated with a relatively narrow range of plants and show stereotyped, taxon-characteristic behavioural patterns in oviposition and feeding ${ }^{2}$. However, the convergence among different insect orders/families and variation among closely related species make it difficult to differentiate miners based on their mine shapes ${ }^{51}$.

The taxonomic affinity of the mines at Momonoki is herein examined in the light of mine shape, the extant groups of fern-pinnule miners, and the chronological origins of possible culprits. The overall mine shape is not comparable to those of known mining structures by extant fern-miners ${ }^{52}$. Extant fern-mining insects are found in four orders: Diptera, Coleoptera, Lepidoptera, and Hymenoptera ${ }^{53}$. In particular, the evidence currently available is not consistent with an affinity to Diptera or Hymenoptera. Flies are relatively diverse as miners of fern pinnules (and stems), represented by Chirosia (Anthomyiidae), Agromyzidae, and Cecidomyiidae ${ }^{53}$. For example, Chirosia is a genus of which all extant taxa are fernminers as larvae; they consume either fronds or stems of a range of fern taxa ${ }^{52,54-59}$. Dipteran leaf mines tend to contain fluidized frass, which is often deposited as two discontinuous rows of pellets ${ }^{19}$; these are not seen in the Cladophlebis mine. No evidence for the presence of dipteran leaf-mining taxa is available for the Late Triassic, although nematocerans and some of the earliest groups of brachycerans are markedly diverse ${ }^{44,45}$. The mine producer is less likely to be affiliated with Hymenoptera, although this order was already diverse by the end of the Triassic ${ }^{60}$, with the oldest fossils dating back to the Middle 
Triassic $^{61}$. The extant fern-feeders of Hymenoptera do not include pinnule-miners, and only Blasticotomidae and Tenthredinidae, as petiole-borers and internal fern-feeders, respectively, are known ${ }^{53}$.

Altogether, the shape of the Cladophlebis mine is not clearly comparable with typical mines of Diptera and Hymenoptera; instead, it can better be assigned to those of Coleoptera or Lepidoptera in terms of the time of appearance and the mine shapes. Beetles became widespread worldwide in the Middle to Late Triassic $^{62-64}$. The earliest beetle group, Protocoleoptera, are found from the Momonoki Formation ${ }^{34,43}$, although they are thought to be saproxylic (i.e., borers of decaying wood), based on some circumstantial evidence $^{65}$. Linear mines containing granular faecal pellets from the Triassic are often assigned to beetles, assuming some lineages of Polyphaga are the candidates ${ }^{66}$.

Lepidopteran mines exhibit considerable variation in mine shape, tissue consumption, and contents (e.g., faecal pellets). Notably, leaf mines of Ectoedemia (Nepticulidae) typically start as fine, strongly meandering galleries that subsequently become broad blotches ${ }^{67}$. In addition, typical nepticulids generally avoid leaf veins and leave granular pellets, with abrupt changes in the accumulation pattern in some species. Importantly, these mine features are seen in the Cladophlebis mine from the Momonoki Formation. Regarding the evolutionary history of nepticulids, based on a recent fossil-calibrated molecular phylogeny ${ }^{68}$, the appearance of leaf-mining moth clades, including Nepticuloidea, dates back to the latest Triassic; for calibrating this phylogeny, wing-scale fossils of Coelolepida from the TriassicJurassic boundary of Germany were used ${ }^{69}$. However, the Cladophlebis mine is not straightforwardly comparable to those of extant nepticulids because no extant nepticulid species feeds on ferns.

\section{The stoichiometric footprint of the studied plant-insect interaction}

The elemental analyses indicate quantitative variability in some elements $(\mathrm{Si}, \mathrm{P}, \mathrm{S})$ that may partly be responsible for physiological processes in nutritional cycles (Fig.3); plant tissues are deposited and then partly removed by an insect and then the insect metabolizes and excretes the undigested substances. The content of frass is thus the product of absorption, metabolism, and excretion. Compared to the leaf vein, the fossilized frass (coprolites) are shown to be highly phosphatic.

Another notable point is the varying intensity of Si among sample points. For the leaf lamina, biogenic and lithologic Si may be conjugated, and thus caution is needed in interpreting our result that the highest intensity of Si was found in the leaf lamina. However, the incremental difference of Si between the frass and leaf vein may be the result of biogenic silica contained in the frass. Biomineralization of silica, especially in the form of phytoliths $\left(\mathrm{SiO}_{2}, \mathrm{nH}_{2} \mathrm{O}\right)$, is found in many clades of pteridophytes ${ }^{70,71}$, and these phytoliths can enhance plant resistance to herbivore feeding ${ }^{72,73}$. This relatively higher content of $\mathrm{Si}$ in the frass coprolites may therefore reflect undigested defensive compounds. 
The elemental analyses shed new light on how this plant-herbivore interaction which occurred 220 million years ago, is mediated by plant chemicals. Furthermore, this study illustrates that ecological stoichiometry, a method that traces the flow of energy and elements in ecosystems, can be applied to interactions between plants and endophytic herbivores in the fossil record. Future investigations of plant chemical landscapes (nutrition and defence) across various temporal and spatial settings would provide new insights into the macroevolutionary patterns of combat between plants and herbivores.

\section{Origin and early history of leaf-mining}

Credible leaf mines are absent or very rare before the Late Triassic ${ }^{27}$. From the Palaeozoic, at least two types of trace fossils have been previously assigned as possible leaf mines, although this is currently not supported. One type concerns U- or V-shaped structures on pinnules of medullosans from the Upper Carboniferous, or Lower Permian ${ }^{74,75}$, which were later attributed to fungal or bacterial infection $27,76,77$. The other type represents a series of small and extensive serpentine structures ${ }^{74,78,79}$, the ichnotaxon name of which is Asteronomus (?) meandriformis; currently, these are acknowledged as structures of taphonomic origin ${ }^{27}$. A notable example from the Early Permian is a possible mine on a megaphyll of Glossopteris cf. indica from the Rio Bonito Formation, Morro do Papaléo Mine, Brazil; this structure contained the possible frass of the miner and ended with a terminal expansion, which was possibly a larval/pupal chamber (Adami-Rodrigues et al., 2004). Another example is a U-shaped contour on the foliage of Vjaznikopteris rigida from the Volga River Basin (the P-Tr boundary), European Russia (Krassilov and Karasev, 2008). However, the identity of these traces as leaf mines is disputable because the above-mentioned criteria for insect mines are not met.

From the Middle-Late Triassic, several distinct shapes of mining structures are known (Fig.4), and some of them are described as distinct damage types (DT) ${ }^{82}$. Several sites of the Molteno Formation (Carnian) are a rich source of herbivory and oviposition trace fossils ${ }^{66,83}$. Two types of leaf mines, one of each from Heidiphyllum elongatum foliage (DT41, DT71) and one from Sphenobaiera schenckii (DT139), have been recorded from this locality ${ }^{66}$ (Fig. 4A); additionally, this locality bears an undescribed, well-preserved mine on Cladophlebis fern pinnules (Labandeira, C. C., pers. comm.), although its shape differs considerably from the one from the Momonoki Formation. Another record from the Gondowanan flora is a serpentine mine on Heidiphyllum foliage, Triassohyponomus dinmorensis, from the Blackstone Formation (Carnian) of the Ipswich Coal Measures Group, Queensland, Australia ${ }^{84,85}$ (Fig. 4B). Some trace fossils from several other localities of the Middle-Late Triassic have also been assigned to leaf mines; for example, a small, semilinear, frass-laden mining structure (DT40) on foliage of the pteridosperm Scytophyllum bergeri, from Monte Agnello, N. Italy (Late Ladinian) ${ }^{86}$ (Fig. 4C). Some mining structures are also known from the foliage of Nilssonia sturii from the Lunz Formation (Carnian), in the eastern part of the Northern Calcareous Alps, Austria ${ }^{87}$ (Fig. 4D); also, two types of mines on some gymnosperm (?Glossophyllum) foliage are reported from Dzhayloucho (Ladinian-Carnian), near Madygen, Kyrghyzstan ${ }^{88,89}$ (Fig. 4E). 
The Cladophlebis mine (Fig. 4F) described here represents a novel damage type that serves as the oldest credible fossil mine from the Southern Floristic Region of East Asia, the palaeobotanical assemblage of which is geographically and taxonomically distant from any of the above-mentioned floras (Fig. 4G). Our finding, therefore, reinforces the view that leaf-mining had become a pervasive feeding method for plantfeeding insects by the Late Triassic. By this time, they had already colonized a wide range of plant groups: conifers, pteridosperms, cycadophytes, ginkgophytes, and ferns.

\section{Declarations}

\section{Acknowledgments}

We thank members of the Mine City Museum of History and Folklore and the Mine Fossil Museum; Hiroyuki Makara (ITCFP) and Soichiro Kawabe (FPDM/FPU) for assisting with XRF analyses; Makoto Kato for providing us with valuable information on extant leaf-mining insects; Conrad C. Labandeira for discussion and sharing unpublished data; Robert B. Davis for proofreading the earlier version of the manuscript. This study was supported by a research grant for Environmental Field Research by the Asahi Glass Foundation (Asahi Glass Co., Ltd.), Grant-in-Aid for Scientific Research (KAKENHI) grant numbers JP20K15852 (Y.I.) and JP19J20625 (N.O.) from the Japan Society for the Promotion of Science (JSPS).

\section{Competing interests}

The authors declare no competing interests.

\section{Author contributions statement}

Y.I. conceived the project. Y.I., N.O., and H.Y. contributed to the data collection of trace fossils. Y.I. analysed the data and wrote the paper with input from all co-authors. Y.I. made the illustrations, visualizations, and drawings, and interpreted the data with input from H.Y., N.O., and F.T. H.Y. identified the host plant, performed XRF analyses, and provided palaeobotanical and geological input. N.O. took photos and provided palaeoentomological input. F.T. collected the specimen. K.S. contributed to the curation of the museum collection. All co-authors commented on the drafts of the manuscript and approved the final manuscript for publication.

\section{Data availability}

The fossil material is housed in the Mine City Museum of History and Folklore (MMHF), Yamaguchi prefecture, Japan: catalogue numbers MMHF11-00001a and MMHF11-00001b. In addition, the original XRF analysis data are provided in Supplementary Information S1-S4. 


\section{Additional Information}

Supplementary information S1. The raw data of X-ray fluorescence (XRF) analyses on sample point A (frass).

Supplementary information S2. The raw data of X-ray fluorescence (XRF) analyses on sample point B (vein).

Supplementary information S3. The raw data of X-ray fluorescence (XRF) analyses on sample point C (lamina).

Supplementary information S4. The raw data of X-ray fluorescence (XRF) analyses on sample point D (rock).

\section{References}

1. Connor, E. F. \& Taverner, M. P. The evolution and adaptive significance of the leaf-mining habit. Oikos 79, 6-25 (1997).

2. Hespenheide, H. A. Bionomics of leaf-mining insects. Annu. Rev. Entomol. 36, 535-560 (1991).

3. Kato, M. Structure, organization, and response of a species-rich parasitoid community to host leafminer population dynamics. Oecologia 97, 17-25 (1994).

4. López, R., Carmona, D., Vincini, A. M., Monterubbianesi, G. \& Caldiz, D. Population dynamics and damage caused by the leafminer Liriomyza huidobrensis blanchard (Diptera: Agromyzidae), on seven potato processing varieties grown in temperate environment. Neotrop. Entomol. 39, 108-114 (2010).

5. Lopez-Vaamonde, C., Godfray, H. C. J. \& Cook, J. M. Evolutionary dynamics of host-plant use in a genus of leaf-mining moths. Evolution 57, 1804-1821 (2003).

6. Lopez-Vaamonde, C. et al. Fossil-calibrated molecular phylogenies reveal that leaf-mining moths radiated millions of years after their host plants. J. Evol. Biol. 19, 1314-1326 (2006).

7. Scheffer, S. J., Lewis, M. L., Hébert, J. B. \& Jacobsen, F. Diversity and host plant-use in North American Phytomyza Holly Leafminers (Diptera: Agromyzidae): colonization, divergence, and specificity in a host-associated radiation. Ann. Entomol. Soc. Am. 114, 59-69 (2021).

8. Tooker, J. F. \& Giron, D. The evolution of endophagy in herbivorous insects. Front. Plant Sci. 11, 581816 (2020).

9. Novotny, V. \& Basset, Y. Host specificity of insect herbivores in tropical forests. Proc. R. Soc. B Biol. Sci. 272, 1083-1090 (2005).

10. Lewis, O. T. et al. Structure of a diverse tropical forest insect-parasitoid community. J. Anim. Ecol. 71, 855-873 (2002). 
11. Hirao, T. \& Murakami, M. Quantitative food webs of lepidopteran leafminers and their parasitoids in a Japanese deciduous forest. Ecol. Res. 23, 159-168 (2008).

12. Pocock, M. J. O., Evans, D. M. \& Memmott, J. The robustness and restoration of a network of ecological networks. Science 335, 973-977 (2012).

13. Lopez-Vaamonde, C., Godfray, H. \& Cook, J. Evolutionary dynamics of host plant utilisation in a genus of leaf-mining moths. Evolution 57, 1804-1821 (2003).

14. Leppänen, S. A., Altenhofer, E., Liston, A. D. \& Nyman, T. Phylogenetics and evolution of host-plant use in leaf-mining sawflies (Hymenoptera: Tenthredinidae: Heterarthrinae). Mol. Phylogenet. Evol. 64, 331-341 (2012).

15. Doorenweerd, C., Van Nieukerken, E. J. \& Menken, S. B. J. A global phylogeny of leafmining Ectoedemia moths (Lepidoptera: Nepticulidae): Exploring host plant family shifts and allopatry as drivers of speciation. PLoS One 10, 1-20 (2015).

16. Nakadai, R. \& Kawakita, A. Phylogenetic test of speciation by host shift in leaf cone moths (Caloptilia) feeding on maples (Acer). Ecol. Evol. 6, 4958-4970 (2016).

17. Opler, P. A. Fossil lepidopterous leaf mines demonstrate the age of some insect-plant relationships. Science 179, 1321-1323 (1973).

18. Labandeira, C. C., Dilcher, D. L., Davis, D. R. \& Wagner, D. L. Ninety-seven million years of angiosperminsect association: paleobiological insights into the meaning of coevolution. Proc. Natl. Acad. Sci. U. S. A. 91, 12278-12282 (1994).

19. Winkler, I. S., Labandeira, C. C., Wappler, T. \& Wilf, P. Distinguishing Agromyzidae (Diptera) leaf mines in the fossil record: new taxa from the Paleogene of North America and Germany and their evolutionary implications. J. Paleontol. 84, 935-954 (2010).

20. van Nieukerken, E. J., Doorenweerd, C., Hoare, R. J. B. \& Davis, D. R. Revised classification and catalogue of global Nepticulidae and Opostegidae (Lepidoptera, Nepticuloidea). Zookeys 2016, 65246 (2016).

21. Maccracken, S. A., Sohn, J.-C., Miller, I. M. \& Labandeira, C. C. A new Late Cretaceous leaf mine Leucopteropsa spiralae gen. et sp. nov. (Lepidoptera: Lyonetiidae) represents the first confirmed fossil evidence of the Cemiostominae. J. Syst. Palaeontol. 19, 131-144 (2021).

22. Wilf, P., Labandeira, C. C., Johnson, K. R. \& Ellis, B. Decoupled plant and insect diversity after the endCretaceous extinction. Science 313, 1112-1115 (2006).

23. Donovan, M. P., Wilf, P., Labandeira, C. C., Johnson, K. R. \& Peppe, D. J. Novel insect leaf-mining after the end-Cretaceous extinction and the demise of Cretaceous leaf miners, Great Plains, USA. PLoS One 9, e103542 (2014).

24. Donovan, M. P., Iglesias, A., Wilf, P., Labandeira, C. C. \& Cúneo, N. R. Rapid recovery of Patagonian plant-insect associations after the end-Cretaceous extinction. Nat. Ecol. Evol. 1, 0012 (2017).

25. Donovan, M. P., Wilf, P., Iglesias, A., Cúneo, N. R. \& Labandeira, C. C. Persistent biotic interactions of a Gondwanan conifer from Cretaceous Patagonia to modern Malesia. Commun. Biol. 3, 708 (2020). 
26. Labandeira, C. C. The four phases of plant-arthropod associations in deep time. Geol. Acta 4, 409438 (2006).

27. Labandeira, C. C. Silurian to Triassic plant and hexapod clades and their associations: new data, a review, and interpretations. Arthropod Syst. Phylogen. 64, 53-94 (2006).

28. Katayama, M. Stratigraphical study on the Mine Series. J. Geol. Soc. Japan 46, 127-141 (1939).

29. Maeda, H. \& Oyama, N. Stratigraphy and fossil assemblages of the Triassic Mine Group and Jurassic Toyora Group in western Yamaguchi Prefecture. J. Geol. Soc. Japan 125, 585- 594 (2019).

30. Aizawa, J. Fossil insect-bearing strata of the Triassic Mine Group, Yamaguchi Prefecture. Bull. Kitakyushu Museum Nat. Hist. Hum. Hist. Ser. A. 10, 91-98 (1991).

31. Oyama, N. \& Maeda, H. Madygella humioi sp. nov. from the Upper Triassic Mine Group, Southwest Japan: the oldest record of a sawfly (Hymenoptera: Symphyta) in East Asia. Paleontol. Res. 24, 6471 (2020).

32. Wakita, K., Nakagawa, T., Sakata, M., Tanaka, N. \& Oyama, N. Phanerozoic accretionary history of Japan and the western Pacific margin. Geol. Mag. 1-17 (2018) doi:10.1017/s0016756818000742.

33. Fujiyama, I. Mesozoic Insect Fauna of East Asia Part 1. Introduction and Upper Triassic Faunas. Bull. Natl. Sci. Museum 16, 331-386 (1973).

34. Fujiyama, I. Late Triassic insects from Mine, Yamaguchi, Japan, Part 1. Odonata. Bull. Natl. Sci. Museum, Tokyo, Ser. C17, 49-56 (1991).

35. Ueda, K. A Triassic fossil of scorpion fly from Mine, Japan. Bull. Kitakyushu Museum Nat. Hist. Hum. Hist. Ser., Ser. A. 10, 99-103 (1991).

36. Takahashi, F., Ishida, H., Nohara, M., Doi, E. \& Taniguchi, S. Occurrence of insect fossils from the Late Triassic Mine Group. Bull. Mine City Museum, Yamaguchi Prefect. Japan 13, 1-27 (1997).

37. Kametaka, M. Provenance of the Upper Triassic Mine Group, Southwest Japan. J. Geol. Soc. Japan 105, 651-667 (1999).

38. Naito, G. Plant Fossils from the Mine Group. (Mine City Education Comittee, 2000).

39. Kimura, T. Geographical distribution of Palaeozoic and Mesozoic plants in East and Southeast Asia. Hist. Biogeogr. plate Tecton. Evol. Japan East. Asia 1982, 135-200 (1987).

40. Kimura, T., Naito, G. \& Ohana, T. Baiera cf. furcata (Lindley and Hutton) Braun from the Carnic Momonoki Formation, Japan. Bull. Natl. Sci. Museum 9, 91-114 (1983).

41. Katagiri, T. Pallaviciniites oishii (comb. nov.), a thalloid liverwort from the Late Triassic of Japan. Bryologist 118, 245-251 (2015).

42. Kustatscher, E. et al. Flora of the Late Triassic. in The Late Triassic World, Topics in Geobiology 46 (ed. Tanner, L. H.) 545-622 (2018). doi:10.1007/978-3-319-68009-5_13.

43. Oyama, N., Yukawa, H. \& Maeda, H. Mesozoic insect fossils of Japan: significance of the Upper Triassic insect fauna of the Mine Group, Yamaguchi Pref. Bull. Mine City Museum, Yamaguchi Prefect. Japan 33, 1-13 (2020). 
44. Shcherbakov, D. E., Lukashevich, E. D. \& Blagoderov, V. Triassic Diptera and initial radiation of the order. Int. J. Dipterol. Res. 6, 75-115 (1995).

45. Krzemiński, W. \& Krzemińska, E. Triassic Diptera: descriptions, revisions and phylogenetic relations. Acta Zool. Cracov. 46, 153-184 (2003).

46. Blagoderov, V., Grimaldi, D. A. \& Fraser, N. C. How time flies for flies: diverse Diptera from the Triassic of Virginia and early radiation of the order. Am. Museum Novit. 3572, 1-39 (2007).

47. Lukashevich, E. D., Przhiboro, A. A., Marchal-Papier, F. \& Grauvogel-Stamm, L. The oldest occurrence of immature Diptera (Insecta), Middle Triassic, France. Ann. la Société Entomol. Fr. 46, 4-22 (2010).

48. Schmidt, A. R. et al. Arthropods in amber from the Triassic Period. Proc. Natl. Acad. Sci. 109, 1479614801 (2012).

49. Lara, M. B. \& Lukashevich, E. D. The first Triassic dipteran (Insecta) from South America, with review of Hennigmatidae. Zootaxa 3710, 81-92 (2013).

50. Kimura, T. \& Ohana, T. Some fossil ferns from the Middle Carnic Momonoki Formation, Yamaguchi prefecture, Japan. Bull. Natl. Sci. Museum, Ser. C, Geol. Paleontol. 6, 73-92 (1980).

51. Hering, E. M. Biology of the Leaf Miners. (Springer Netherlands, 1951). doi:10.1007/978-94-0157196-8.

52. Eiseman, C. Leafminers of North America. (2019). doi:10.22456/2527-2616.75900.

53. Yang, J., Wang, X., Duffy, K. \& Dai, X. A preliminary world checklist of fern-mining insects. Biodivers. Data J. 9, e62839 (2021).

54. Meikle, A. A. The insects associated with bracken. Agrucultural Prog. 14, 58-61 (1937).

55. Lawton, J. H. The structure of the arthropod community on bracken. Bot. J. Linn. Soc. 73, 187-216 (1976).

56. Lawton, J. H., MacGarvin, M. \& Heads, P. A. Effects of altitude on the abundance and species richness of insect herbivores on bracken. J. Anim. Ecol. 56, 147-160 (1987).

57. Cooper-Driver, Gi. A. Insect-Fern Associations. Entomol. Exp. Appl. 24, 310-316 (1978).

58. Eiseman, C. S. Further Nearctic Rearing Records for Phytophagous Muscoid Flies (Diptera: Anthomyiidae, Scathophagidae). Proc. Entomol. Soc. Washingt. 122, 595-603 (2020).

59. Santos, M. G. \& Maia, V. C. A synopsis of fern galls in Brazil. Biota Neotrop. 18, e20180513 (2018).

60. Peters, R. S. et al. Evolutionary history of the Hymenoptera. Curr. Biol. 27, 1013-1018 (2017).

61. Ronquist, F. et al. A total-evidence approach to dating with fossils, applied to the early radiation of the Hymenoptera. Syst. Biol. 61, 973-999 (2012).

62. Zheng, D. et al. Middle-Late Triassic insect radiation revealed by diverse fossils and isotopic ages from China. Sci. Adv. 4, eaat1380 (2018).

63. Zhang, S. Q. et al. Evolutionary history of Coleoptera revealed by extensive sampling of genes and species. Nat. Commun. 9, 1-11 (2018).

64. McKenna, D. D. et al. The evolution and genomic basis of beetle diversity. Proc. Natl. Acad. Sci. 116, 24729-24737 (2019). 
65. Gimmel, M. L. \& Ferro, M. L. General Overview of Saproxylic Coleoptera. in Saproxylic Insects, Zoological Monographs 1 (ed. Ulyshen, M. D.) 51-128 (2018). doi:10.1007/978-3-319-75937-1_2.

66. Labandeira, C. C., Anderson, J. M. \& Anderson, H. M. Expansion of Arthropod Herbivory in Late Triassic South Africa: The Molteno Biota, Aasvoëlberg 411 Site and Developmental Biology of a Gall. in The Late Triassic World, Topics in Geobiology 46 (ed. Tanner, L. H.) 623-719 (Springer International Publishing AG, 2018). doi:10.1007/978-3-319-68009-5_14.

67. Doorenweerd, C., Van Nieukerken, E. J., Sohn, J. C. \& Labandeira, C. C. A revised checklist of Nepticulidae fossils (Lepidoptera) indicates an Early Cretaceous origin. Zootaxa 3963, 295-334 (2015).

68. Kawahara, A. Y. et al. Phylogenomics reveals the evolutionary timing and pattern of butterflies and moths. Proc. Natl. Acad. Sci. 116, 22657-22663 (2019).

69. Van Eldijk, T. J. B. et al. A Triassic-Jurassic window into the evolution of lepidoptera. Sci. Adv. 4, e1701568 (2018).

70. Mazumdar, J. Phytoliths of pteridophytes. South African J. Bot. 77, 10-19 (2011).

71. Trembath-Reichert, E., Wilson, J. P., McGlynn, S. E. \& Fischer, W. W. Four hundred million years of silica biomineralization in land plants. Proc. Natl. Acad. Sci. U. S. A. 112, 5449-5454 (2015).

72. Hunt, J. W., Dean, A. P., Webster, R. E., Johnson, G. N. \& Ennos, A. R. A novel mechanism by which silica defends grasses against herbivory. Ann. Bot. 102, 653-656 (2008).

73. Reynolds, O. L., Keeping, M. G. \& Meyer, J. H. Silicon-augmented resistance of plants to herbivorous insects: A review. Ann. Appl. Biol. 155, 171-186 (2009).

74. Müller, A. H. Über Hyponome fossiler und rezenter Insekten, erster Beitrag. Freib. Forschungsh. C 366, 7-27 (1982).

75. Beck, A. L. \& Labandeira, C. C. Early Permian insect folivory on a gigantopterid-dominated riparian flora from north-central Texas. Palaeogeogr. Palaeoclimatol. Palaeoecol. 142, 139-173 (1998).

76. Jarzembowski, E. A. The oldest plant-insect interaction in Croatia: Carboniferous evidence. Geol. Croat. 65/3, 387-392 (2002).

77. Donovan, M. P. \& Lucas, S. G. Insect herbivory on the Late Pennsylvanian Kinney Brick Quarry Flora, New Mexico, USA. in Kinney Brick Quarry Lagerstätte. New Mexico Museum of Natural History and Science Bulletin 84 vol. 3 193-207 (2021).

78. Potonié, R. Ueber das Rothliegende des Thüringer Waldes. Theil II: Die Flora des Rothliegenden von Thüringen. Abh.Preuss.Geol.Landesanst. 9, 1-298 (1893).

79. Potonié, R. Mitteilungen über mazerierte kohlige Pflanzenfossilien. Zeitschrift für Bot. 79-88 (1921).

80. Adami-Rodrigues, K. A., lannuzzi, R. \& Pinto, I. D. Permian plant-insect interactions from a Gondwana flora of southern Brazil. Foss. Strat. 51, 106-126 (2004).

81. Krassilov, V. A. \& Karasev, E. First evidence of plant - arthropod interaction at the Permian - Triassic boundary in the Volga Basin, European Russia. Alavesia 2, 247-252 (2008). 
82. Labandeira, C. C., Wilf, P., Johnson, K. \& Marsh, F. Guide to insect (and other) damage types on compressed plant fossils. Version 3.0. Smithson. Institution, Washington, DC 25 (2007).

83. Scott, A. C., Anderson, J. M. \& Anderson, H. M. Evidence of plant-insect interactions in the Upper Triassic Molteno formation of South Africa. J. Geol. Soc. London. 161, 401-410 (2004).

84. Tillyard, R. J. Mesozoic Insects of Queensland. No. 9. Orthoptera, and Additions to the Protorthoptera, Odonata, Hemiptera, and Planipennia. Proc. Linn. Soc. New South Wales 47, 447-470 (1922).

85. Rozefelds, A. C. \& Sobbe, I. Problematic insect leaf mines from the Upper Triassic Ipswich Coal Measures of Southeastern Queensland, Australia. Alcheringa 11, 51-57 (1987).

86. Wappler, T., Kustatscher, E. \& Dellantonio, E. Plant-insect interactions from Middle Triassic (late Ladinian) of Monte Agnello (Dolomites, N-Italy)-Initial pattern and response to abiotic environmental pertubations. PeerJ 2015, e921 (2015).

87. Meller, B., Ponomarenko, A. G., Vasilenko, D. V., Fischer, T. C. \& Aschauer, B. First beetle elytra, abdomen (Coleoptera) and a mine trace from Lunz (Carnian, Late Triassic, Lunz-am-See, Austria) and their taphonomical and evolutionary aspects. Palaeontology 54, 97-110 (2011).

88. Vassilenko, D. V. Traces of plant-arthropod interactions from Madygen (Triassic, Kyrgyzstan): preliminary data. in Sovremennaya paleontologia: klassicheskie i noveishie metody 9-15 (PIN RAS, Moscow, 2009).

89. Zherikhin, V. V. Insect Trace Fossils. in History of Insects 303-324 (Kluwer Academic Publishers, 2010).

90. Takahashi, E. \& Mikami, T. Triassic. in Geology of Yamaguchi Prefecture (ed. Yamaguchi Museum) 93-108 (1975).

91. Kiminami, K. Atsu Group and Mine Group. in Monograph on Geology of Japan 6, Chugoku Region (ed. Geological Society of Japan) 85-88 (2009).

92. Schindelin, J. et al. Fiji: An open-source platform for biological-image analysis. Nat. Methods 9, 676682 (2012).

93. Wickham, H. ggplot2: Elegant Graphics for Data Analysis. (Springer-Verlag New York, 2016).

\section{Figures}




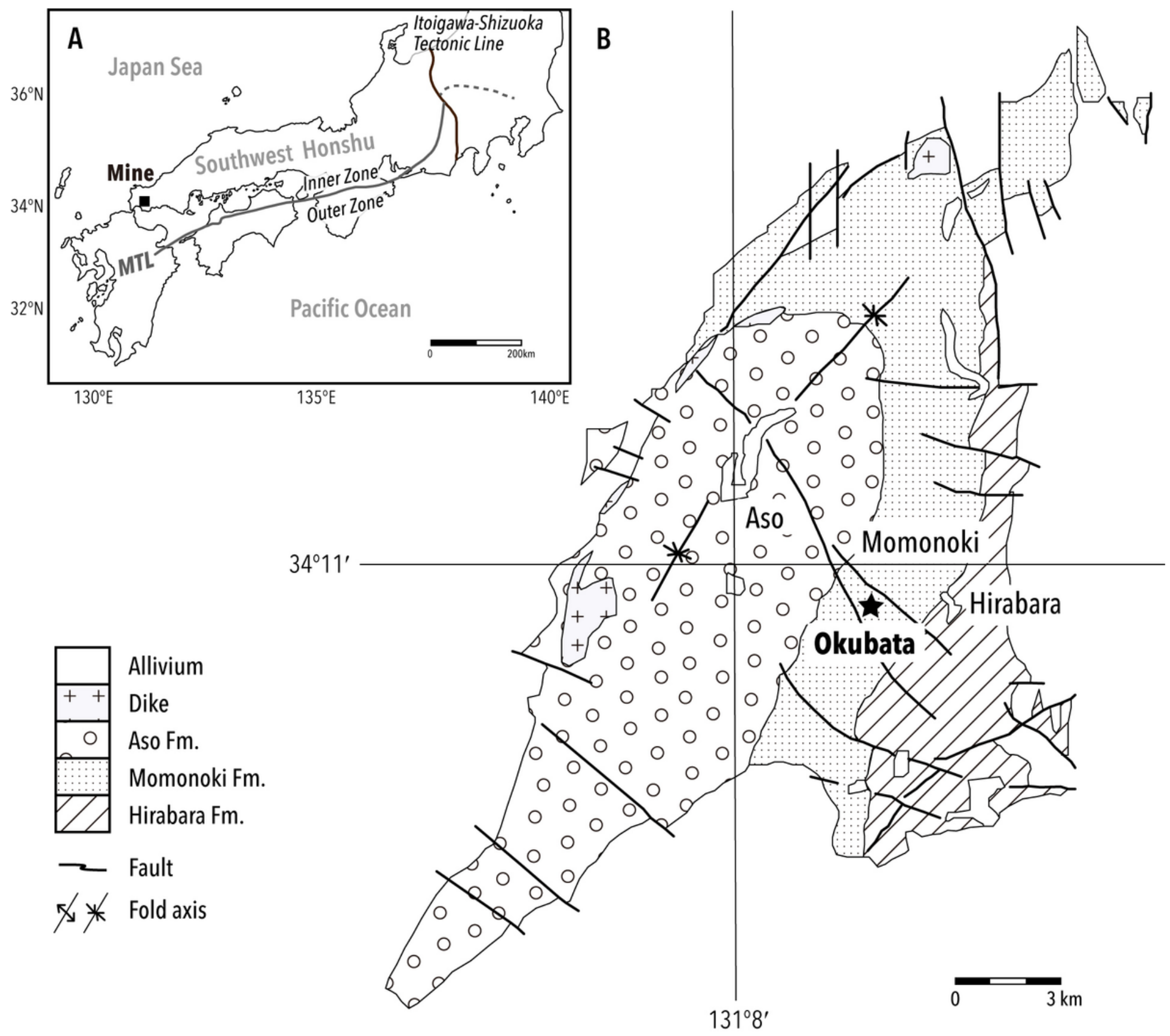

Figure 1

Study site location and geological map. (A) Map showing the fossil site, Mine, Yamaguchi, in southwest Honshu, Japan. Mine is located in the Inner Zone, the region formed by complex faulting along the Median Tectonic Line (MTL) and separated from the Outer Zone (southern side). (B) Geological map of the Mine Group, slightly modified from previous studies 90,91 . The star denotes the holotype fossil locality, Okubata. 

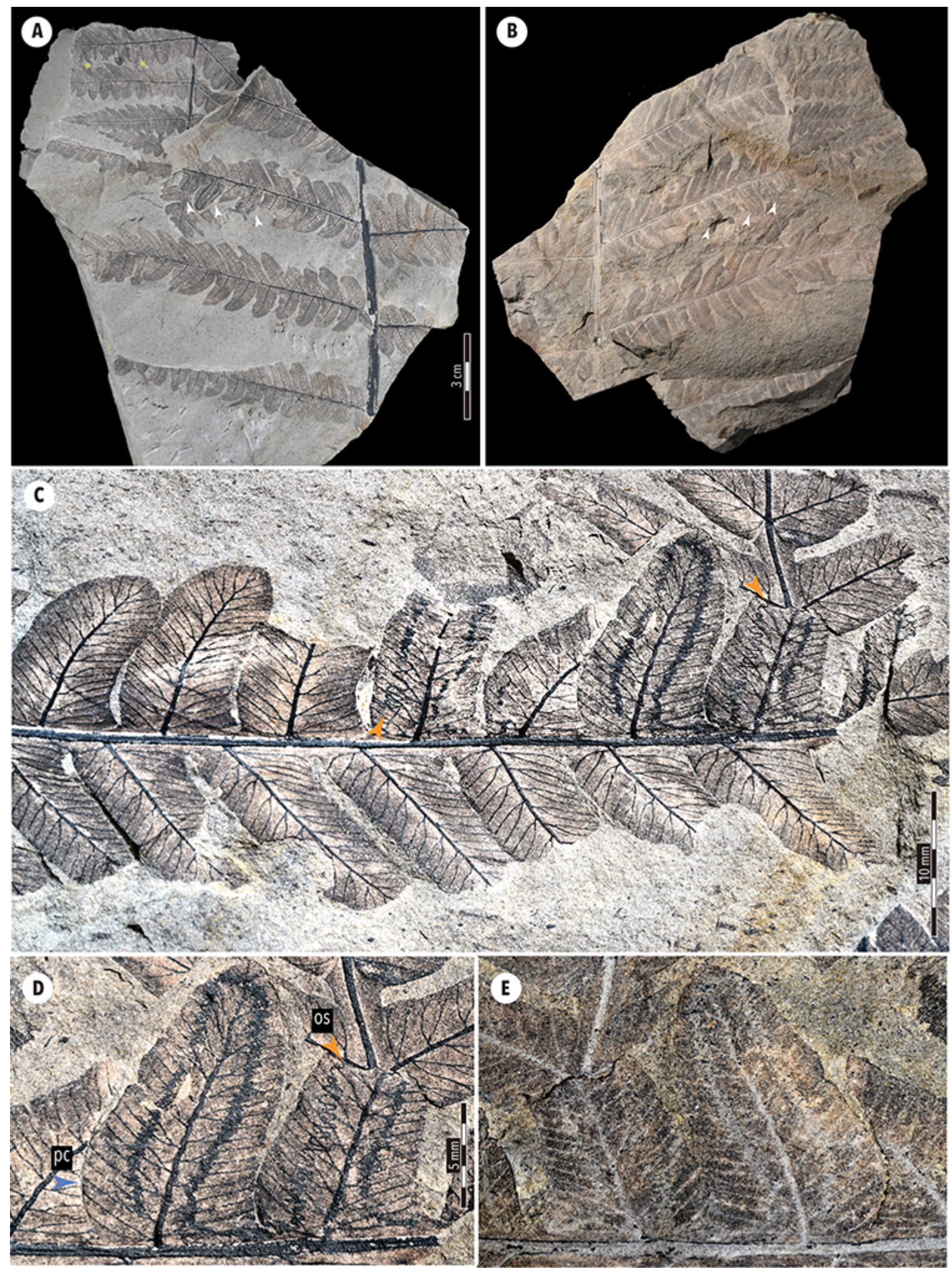

\section{Figure 2}

Late Triassic leaf-mine fossil on Cladophlebis denticulata of the Momonoki Formation, Yamaguchi, Japan. (A) Holotype specimen (MMHF11-00001a), on which mines on pinnules and chewing marks are marked with white arrowheads and yellow asterisks, respectively, and (B) its counterpart (MMHF1100001b), at approximately the same scale. (C) Enlargement of pinna with three mines; orange arrowheads signify putative starting point (i.e., oviposition site) of leaf-mines; however, the starting point 
of the mine on the right is unseen. (D) Enlargement of two pinnules shows the transition of the frass trail, suggesting larval development while mining, and (E) its counterpart at the same scale. Arrowheads in orange and blue denote an oviposition site (os) and possible pupal chamber (pc), respectively.
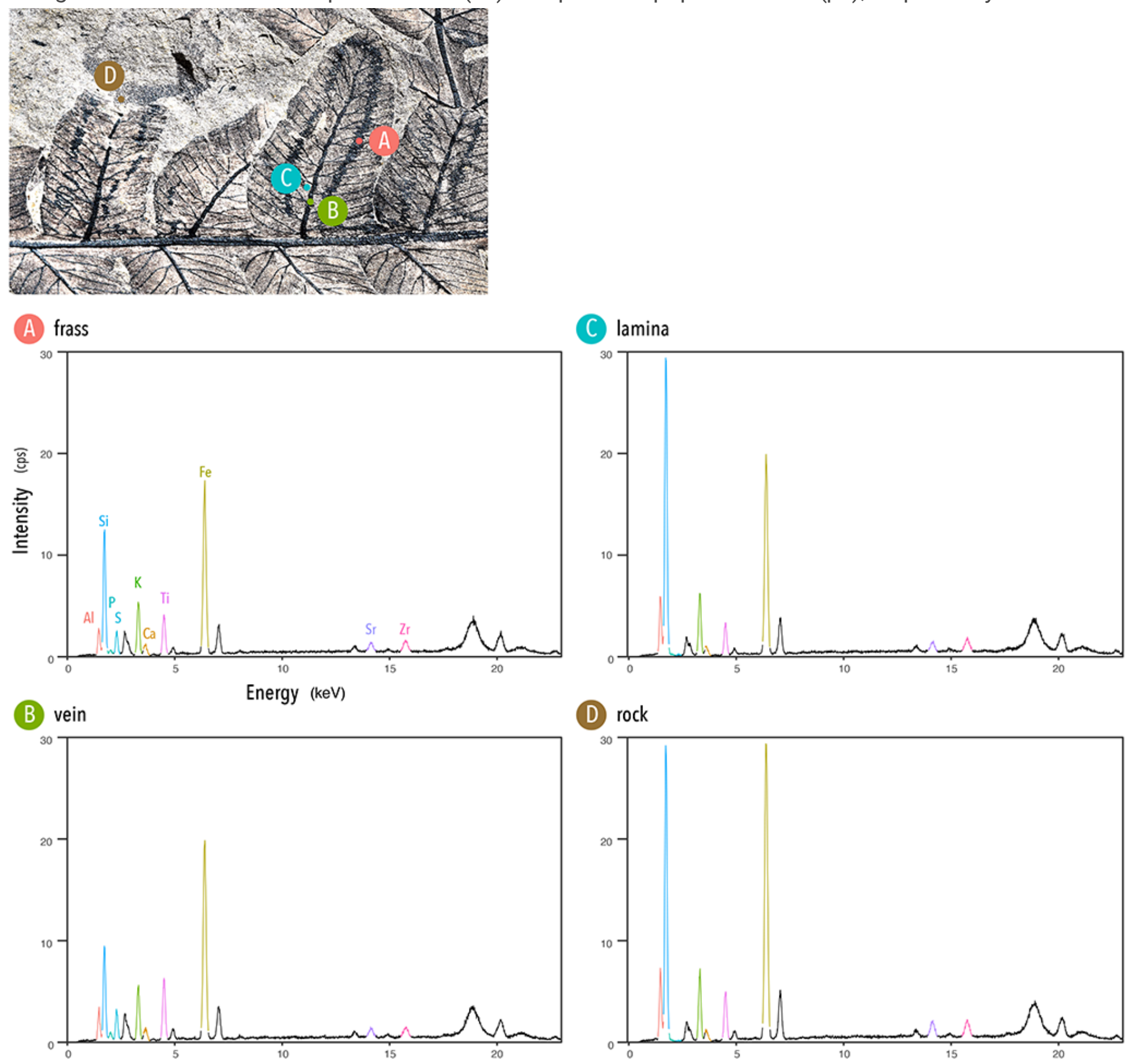

Figure 3

Results of X-ray fluorescence (XRF) analyses conducted with an EA6000VX High Sensitivity XRF Analyzer (Hitachi High-Tech Science Corporation). (Upper panel) Positions of the four sample points are specified on the holotype specimen. (Lower panels) XRF spectra in the range of 0-23 keV illustrated for each sample point A-D. Vertical axes signify cps (X-ray counts per sec). 


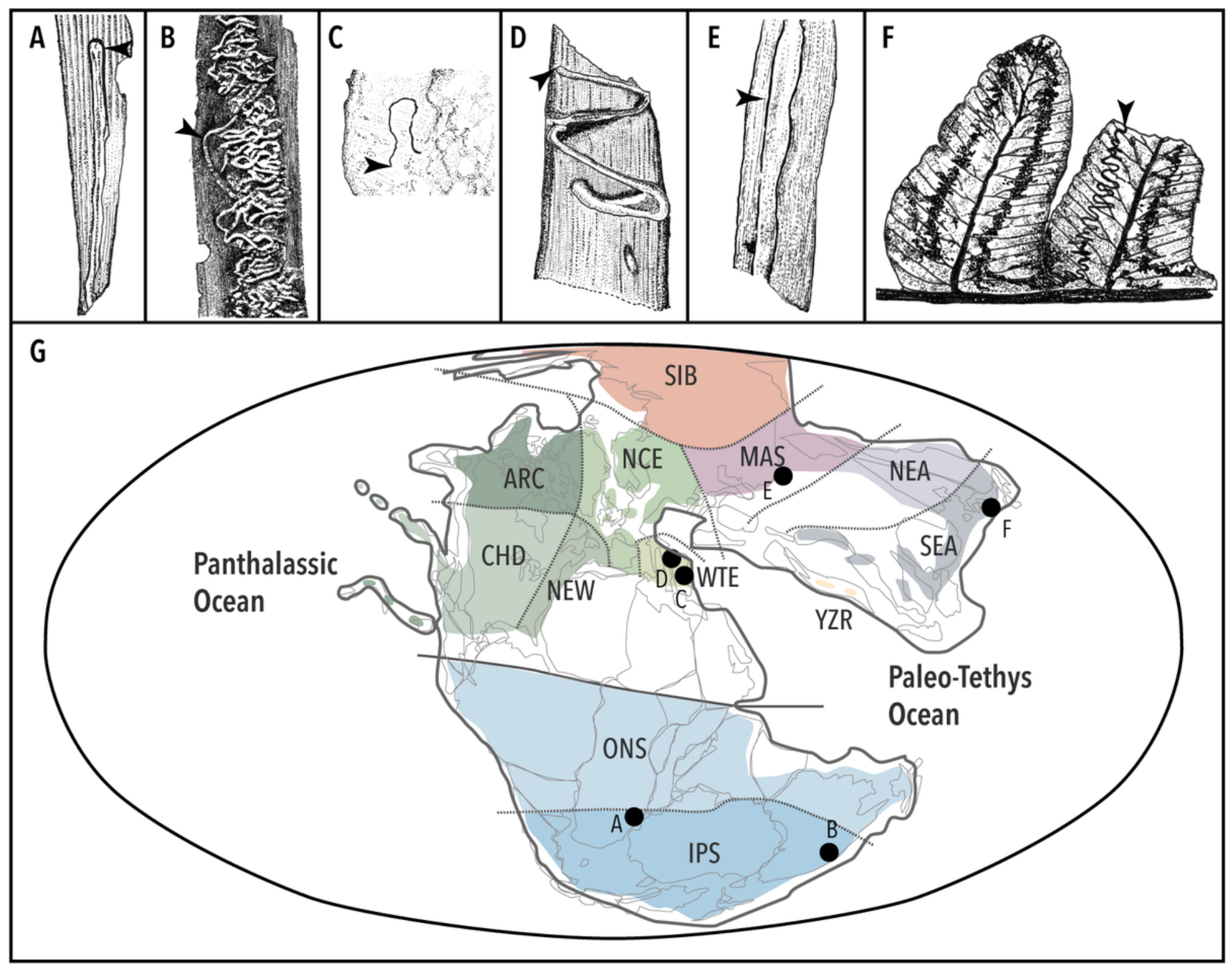

Figure 4

Mining structures known so far from the Middle-Late Triassic. (A) Heidiphyllum foliage mine (DT71) from the Molteno Formation (Carnian)66; two other recorded mines (DT41, DT139) from this formation are unillustrated. (B) Heidiphyllum foliage mine, Triassohyponomus dinmorensis, from the Blackstone Formation (Carnian) of the Ipswich Coal Measures Group, Queensland, Australia85. (C) Pteridosperm foliage mine from Monte Agnello, N. Italy (Late Ladinian)86. (D) Nilssonia foliage mine from the Lunz Formation (Carnian), eastern part of the Northern Calcareous Alps, Austria87. (E) Gymnosperm foliage mine from Dzhayloucho (Ladinian-Carnian), near Madygen, Kyrgyzstan88. (F) Cladophlebis pinnule mines from the Momonoki Formation (our study). (G) Paleogeographic map of the Late Triassic (Carnian) and the approximate locations of fossil mine localities are shown; floral zonation is based on a previous study42. Colours and three-letter acronyms represent floral zones as follows: SIB: Siberian Subprovince; MAS: Middle Asian Subprovince; NEA: Northern East Asian Subprovince; SEA: Southern East Asian Subprovince; ARC: Arctic Canada Subprovince; NCE: North Atlantic/Central European Subprovince; NEW: Newark Subprovince; CHD: Chinle/Dockum Subprovince; WTE: Western Tethydean Subprovince; 
YZR: Yarlung-Zangbo-River Subprovince; ONS: Onslow Subprovince; IPS: Ipswich Subprovince. Line drawings were made by Y.I. with Adobe Illustrator ${ }^{\circledR} 2021$.

\section{Supplementary Files}

This is a list of supplementary files associated with this preprint. Click to download.

- S1.txt

- S2.txt

- S3.txt

- S4.txt 